\title{
12
}

\section{Constitution Making and Democratic Consolidation in Turkey}

\author{
Ergun Özbudun
}

Constitution making, particularly in times of democratic transitions, is an excellent opportunity to build political institutions that will enjoy broad support from the society and its political (and other) elites. Both the constitution-making process and its outcome, that is constitutional choices, are crucial in the transition to and the consolidation of democracy. It has been argued that

constitution making is at once the most varied and the most concentrated form of political activity during the transition. In it, political maneuvering, bargaining and negotiations take place and the political positions, agreements and disagreements between groups and leaders come to the fore. How the constitution drafters handle these issues may tell us crucial things about the transition and about the regime it leads to. ... The general character of both the process and its outcome may reveal clues about the new regime's potential for stability or instability (Bonime-Blanc, 1987: 13).

To put it differently, the constitution-making process influences not only the mode of transition to democracy, but also, and perhaps more importantly, the prospects for the consolidation of democracy. It will be argued here that a consensual or consociational style of constitutionmaking tends to considerably increase the chances for democratic consolidation.

Thus it seems no accident that some of the most stable democratic constitutions of the post-World War II period are the products of broadly representative constituent assemblies and a highly consensual style of constitution making. The best known examples are the German, Italian, 
and Spanish constitutions. In Italy, the Constituent Assembly elected in 1946 was dominated by three major parties (the Christian Democrats, the Socialists, and the Communists). While the Christian Democrats were the strongest party, the combined leftists' vote (Communists and Socialists) was higher than that of the Christian Democrats. The latter, however, occupied the central position in the political alignment and were usually successful in producing a realignment of all moderate and conservative forces around themselves. Nevertheless, no single coalition dominated Italian constitution making. "Instead, fluid coalitions and consensual decision making took place on an issue by issue basis. ... Even in the face of ... potentially divisive issues, the process ... was completed on a consensual basis with most, if not all, political parties supporting the final version of the new constitution" (Bonime-Blanc, 1987: 121). The Italian Constitution was highly praised as a true political monument. As Pasquino observes, "So important was that period of collaboration, and so celebrated were its results, that to this day the Communists have stressed that they have little in common with the Christian Democrats, except for the fact that they drafted the constitution together" (Pasquino, 1986: 64).

Similarly, the constitution-making process in post-Franco Spain was dominated by an accommodational, consensual style. Such a style was encouraged by the results of the first free legislative elections of 15 June 1977. The center-right Union of the Democratic Center (UCD) under the leadership of Adolfo Suarez emerged as the largest party with 34.7 percent of the vote and 165 out of 350 (47.1 percent) Cortes seats. The Socialist Party (PSOE) received 29.2 percent of the popular vote and 118 seats (33.7 percent). The two more ideological parties made disappointing showings: the Allianza Popular (AP) with links with the Francoist past received only 8.5 percent of the vote, and the Communists (PCE) obtained 9.3 percent. The new Cortes agreed at its first session that it would meet as a Constituent Assembly. The results of the elections left open the possibility of a rightist UCD-AD coalition in constitution making. However, the UCD rarely resorted to this option. While there were cases of intermittent winning coalitions between these two parties, especially on moral issues, "such a coalition was in no way comprehensive or predominant. Instead of displaying polarization, the Spanish process may be a model of consensual politics where parties of widely differing ideologies, through accommodation, formed the predominant multilateral (consensual) coalition" (Bonime-Blanc, 1987: 143, 154-155). Through painstaking, sometimes secret, deliberations, compromises were reached between the Left and Right on most of the fundamental constitutional issues. The consensual nature of the constitution-making process is reflected in the final vote on the constitution in the Congress and the Senate. The constitution was 
adopted almost unanimously with only few AP and Basque members voting against or abstaining. This is also true of the constitutional referendum of December 6,1978, when the constitution was popularly approved by 87.8 percent of the votes cast (Bonime-Blanc, 1987: 39-42, 5962; Maravall and Santamaria, 1986: 87-89).

At the other end of the spectrum, one may observe a confrontational or dissensual style of constitution making, the best examples of which are the 1946 Constitution of France and the 1976 Constitution of Portugal. The French Constituent Assembly was dominated by three strong, disciplined, and ideologically oriented parties (Communists, Socialists, and the Christian Democratic MRP) that failed to arrive at consensual solutions on a number of important constitutional issues. Consequently, the first draft was rejected in the referendum, and the second one was only narrowly adopted. Judged by the short life of the Fourth French Republic (19461958) and by the chronic governmental instability, this experience cannot be considered a successful one.

Similarly, the special circumstances that surrounded constitution making in post-Salazar Portugal affected both the style of the constitutionmaking process and its outcome. Due to a majority of the leftist parties (Socialists and Communists) in the Constituent Assembly and the influence of radical leftist officers, the process can be described as essentially dissensual rather than consensual. "Decision-making, coalitions and results were ideologically one-sided and achieved unilaterally ... over the heads of the more centrist, second largest party, the People's Democratic Party" (Bonime-Blanc, 1987: 119-122). As for the outcome, the 1976 Constitution was full of ideological, dogmatic, and often purely rhetorical provisions concerning the socioeconomic system. Many of these ideological statements were eliminated or revised in the 1982 constitutional revision. Thus, the full consolidation of democracy in Portugal required two extensive revisions (in 1982 and 1989) of the constitution.

In the light of such comparative evidence, the Turkish experience in constitution making can be described as a series of missed opportunities to create political institutions based on broad consensus. None of the three republican constitutions (those of 1924, 1961, and 1982), not to mention the 1876 Ottoman Constitution, was made by a constituent or legislative assembly broadly representative of social forces nor through a process of negotiations, bargaining, and compromise. Consequently, they all enjoyed weak political legitimacy. 


\section{The 1924 Constifution}

The first republican constitution of 1924 was made by the Grand National Assembly (GNA) elected in 1923. The 1923 elections were strongly controlled and dominated by the Republican People's Party (RPP) newly organized by Mustafa Kemal and his supporters. None of the deputies who had been opposed to Mustafa Kemal during the first legislative session of the Assembly (1920-1923) had been reelected. Thus, the new legislature was almost completely dominated by the Kemalists, although when it debated the new constitution a single-party system had not yet been consolidated. Therefore, the constitutional debates took place in an atmosphere of relative freedom, even though the Assembly was far from representing all major forces in the society.

Perhaps due to this atmosphere of relative freedom, the outcome of the process was a constitution which appeared democratic in letter and spirit. The 1924 Constitution maintained the Grand National Assembly as the supreme organ of the state, only slightly deviating from the "assembly government" model that prevailed in the early 1920s. The main defect of the Constitution was the lack of a system of effective checks and balances that would check the power of elected majorities. Therefore, when a de facto single-party regime was established in 1925, the Constitution easily became an instrument of authoritarian government. As the RPP leadership effectively controlled and monopolized nominations to the GNA, the supreme powers of the latter came to be exercised by the party leadership and the executive. Hence, there was no need to change the Constitution to adapt it to the requirements of authoritarian government.

By the same token no compelling need was felt to change it in a more democratic direction when the RPP leadership decided to introduce a multi-party democracy in 1945. The Turkish transition to democracy was accomplished with no constitutional revision whatsoever and only some changes in election, press, and association laws. Thanks to an election law adopted in early 1950 and assured free and honest elections under judicial supervision, the opposition Democratic Party (DP) came to power in the elections of May 14, 1950.

The 1924 Constitution remained unchanged during the ten year period when the DP was in power. One may wonder why neither party attempted to introduce more effective constitutional checks and balances in order to lay the foundations of a more liberal and pluralistic democracy. The most plausible answer is that the RPP never seriously thought of losing power and the DP, once in power, found the unlimited majority rule provided by the Constitution to its own political advantage. Therefore, no meaningful 
constitutional dialogue took place between the government and the opposition parties either before or after the change of government in 1950.

However, the lack of such constitutional checks and balances turned out to be the main reason for the collapse of the first Turkish experiment with democracy. In the absence of effective legal guarantees for basic rights and the judicial review of the constitutionality of laws, the DP government felt tempted to pass a series of laws that severely restricted the rights of the opposition. This, in turn, led the opposition to take a harsh attitude toward the government. The ensuing public unrest resulted in the military intervention of May 27, 1960, which overthrew the DP government and set up a temporary military regime.

\section{The 1961 Constitution}

The 1960 coup was carried out by a group of middle-rank officers who, upon assuming power, organized themselves into a revolutionary council named the National Unity Committee (NUC), under the chairmanship of General Cemal Gürsel, the former commander of the army. The NUC declared from the beginning its intention of making a new democratic constitution and returning power to a freely elected civilian government. In spite of the efforts by some NUC members to prolong military rule, the Committee kept to its promise and relinquished power in 1961, following the parliamentary elections held under the new Constitution and the Electoral Law.

However, the new Constitution was made in less than fully democratic circumstances. The NUC remained as one of the chambers of the bicameral Constituent Assembly. Therefore, the military's influence was strongly felt in the making of the Constitution. Nor was the civilian chamber (the House of Representatives) a fully representative body. Nearly one-third of its members were chosen by indirect elections. The rest were appointed or coopted by the two opposition parties the (RPP and the Republican Peasant Nation Party), the Head of the State (General Gürsel), the NUC and such institutions as the judiciary, the universities, bar associations, chambers of commerce and industry, trade unions, press associations, youth organizations, and so on. More importantly, the supporters of the banned DP, which represented roughly half of the Turkish electorate, were not represented at all in the Constituent Assembly.

The Constituent Assembly was thus largely dominated by the state elites (the military, the bureaucracy, and the university professors) and by the RPP which was the principal spokesperson of these elites. Consequently, the 1961 Constitution, adopted by the Assembly and ratified by popular vote by a majority of 61.7 percent, reflected the basic political 
values and interests of the state elites. Thus, on the one hand, the constitution greatly expanded civil liberties and granted extensive social rights. On the other hand, it reflected a certain distrust of politicians and elective assemblies by creating an effective system of checks and balances to limit the power of such elected organs. These checks included the introduction of judicial review of the constitutionality of laws; the strengthening of the administrative courts with review powers over all the acts of executive agencies; full independence for the judiciary; the creation of a second chamber of the legislative assembly; improvement of job security for civil servants and especially judges; and the granting of substantial administrative autonomy to certain public agencies such as the universities and the Radio and Television Corporation. It was hoped that the power of the elected assemblies would be effectively balanced by judicial and other bureaucratic agencies, and that the newly expanded civil liberties and social rights would ensure the gradual development of a genuinely pluralistic and democratic society.

With regard to the regulation of socioeconomic life, the majority of the Constituent Assembly gave the old Kemalist notion of étatism a more leftist and ideological interpretation. Consequently, many programmatic or ideological statements were incorporated into the Constitution. Thus, the state was entrusted with the tasks of economic, social, and cultural planning; carrying out a land reform; providing health care and housing; creating social security organizations; helping to assure full employment, and the like. The state was also empowered to take measures to force private enterprises to act "in accordance with the requirements of national economy and with social objectives" (Article 49).

Neither the circumstances of the making of the 1961 Constitution, nor its substance made it possible for the Constitution to be accepted by a large majority of Turkish society. The former Democrats, partly because they were totally excluded from the constitution-making process, voted against it in the constitutional referendum of July 9, 1961. The Justice Party (JP) which came to power in 1965 as the established heir to the banned DP had an ambivalent attitude toward the Constitution. While it took care to operate clearly within its limits, it criticized those aspects of it that, in its view, gave excessive powers to bureaucratic and judicial agencies. The JP leaders often expressed the view that the Constitution created an "ungovernable" political system and demanded a stronger executive. Nor were they comfortable with the extensive social rights recognized by the Constitution and its other left-leaning provisions. The views of Celal Bayar, the deposed president of the Republic under the DP regime, were both more systematic and more extreme on the 1961 Constitution. Bayar argued that the 1924 Constitution was more in accordance with the Kemalist 
notion of unconditional sovereignty of the nation, because it concentrated all power in the Grand National Assembly as the sole representative of the Turkish nation. The 1961 Constitution, on the other hand, introduced new partners into the exercise of national sovereignty: the army and the intellectuals. Thus, it reflected a distrust of elected assemblies and represented a return to the Ottoman notion of tripartite (palace, army, and religious scholars) government (Tanör, 1986: 29-37, 61-67). No doubt, such negative views of the 1961 Constitution were also partly motivated by the fact that the DP-JP was considered as the "natural" majority party in the 1950s and 1960 s, and therefore it was resentful of bureaucratic limitations upon the power of elected assemblies.

\section{The 1971 and 1973 Constitutional Revisions}

It appears, however, that the tension between state elites and the JP as the principal representative of political elites tended to decrease in the late 1960s. The JP government treated the military with much greater care and respect than the DP government had. The National Security Council, an advisory body created by the 1961 Constitution and composed of certain ministers and the highest commanders of the Armed Forces, gave the military a legitimate voice in the formulation of national security policies. The election by the Grand National Assembly of former military commanders as presidents of the Republic (General Gürsel in 1961 and General Sunay in 1966) was also a reassuring factor for most officers. Finally, salaries and other side benefits for officers were greatly improved in the 1960s. Although a strong radical faction within the Armed Forces was still quite unhappy with the JP government and its basically conservative policies, its conspiratorial activities failed to gain support of the top military leadership. These radical officers, frustrated by the successive electoral victories of the JP, aimed at establishing a longer-term military regime to carry out radical social reforms. In fact, the military memorandum of March 12, 1971, which forced the JP government to resign, was a last minute move by the top military commanders to forestall a radical coup. In the days following the memorandum, most of the radical officers were summarily retired or dismissed, thereby strengthening the position of the more conservative leadership of the military. The so-called March 12th regime did not go as far as dissolving the parliament and assuming power directly. Instead, it urged the formation of an "above-party" or technocratic government under a veteran RPP politician, Professor Nihat Erim.

The policies of the nonparty government, with strong behind-the-scenes support from the military, were more in line with the JP's conservative philosophy. This is also evident in the extensive constitutional amend- 
ments of 1971 and 1973, which incorporated most of the JP's positions into the constitution. These amendments can be grouped into three categories: (a) curtailment of certain civil liberties in conjunction with restrictions brought upon the review powers of the courts; (b) the strengthening of the executive, particularly by allowing the Grand National Assembly to grant it law-making powers; (c) increasing the institutional autonomy of the military by excluding it from the review of the civilian administrative courts and the Court of Account.

With the possible exception of the last item, the amendments were in accordance with the JP's constitutional thesis. Therefore, the JP (and other conservative) deputies readily voted in favor of the amendments. To obtain the two-thirds majority required for constitutional change, pressures were apparently exerted upon the RPP leadership and its deputies. The threat of the dissolution of Parliament, clearly expressed in the March 12 memorandum, and the highly repressive atmosphere produced by the martial law regime also weakened and discouraged the opposition (Tanör, 1986: 3960 ). Thus, once again constitutional change was accomplished by highly dissensual methods without a genuine process of negotiations and compromise among political parties. One side imposed its favored solutions upon the other by taking advantage of the threat of force by the military.

\section{The 1982 Constitution}

The making of the 1982 Constitution is another missed opportunity to create political institutions enjoying broad consensus. Although the National Security Council (composed of the five highest ranking generals in the Turkish armed forces) that took over the government on September 12, 1980 made it clear that it intended to eventually return power to democratically elected civilian authorities, it made equally clear that it did not intend a return to the status quo ante. Rather, the Council aimed at a major restructuring of Turkish democracy to prevent the recurrence of the political polarization, violence, and deadlock that had afflicted the country in the late 1970s.

This restructuring was done by a Constituent Assembly created by the National Security Council (NSC). As in the case of the 1960-1961 Constituent Assembly, this was a bicameral structure, one chamber of which was the NSC itself. However, there were important differences between this Constituent Assembly and its predecessor. In the present case, the civilian chamber (Consultative Assembly) was even less representative in character than the House of Representatives of the 1960-1961 period. While the latter included the representatives of the two opposition parties and various other institutions, the former was an entirely appointed body; all 
its members were appointed by the NSC. Furthermore, no political party members were eligible to become members of the Consultative Assembly. Consequently, the state elites had even more weight in the Consultative Assembly than in the House of Representatives. Secondly, the Consultative Assembly had much less power vis-à-vis the NSC, compared to the House of Representatives vis-à-vis the NUC. While in the latter case the two chambers had roughly equal powers in the adoption of the constitution and other laws, in the former the NSC kept the final say. In other words, the NSC had the absolute power to amend or reject the constitutional draft prepared by the Consultative Assembly, with no machinery envisaged to resolve the differences between the two chambers. Thirdly, whereas the constitutional referendum of 1961 took place in a reasonably free atmosphere and those who were against the constitution (particularly the JP) were able to propagate their views, the referendum of 1982 followed an entirely one-sided campaign conducted by General Evren, the Head of State and the Chairman of the NSC. An NSC decree prohibited the expression of any views intended to influence the decision of voters, and banned any criticism of the transitional articles of the Constitution and of the speeches made by General Evren in his pro-constitution campaign. Finally, the constitutional referendum was combined with the election of the president of the Republic. A "yes" vote for the Constitution also meant the endorsement of the presidency of General Evren (the sole candidate) for a seven-year period. Under these circumstances, the Constitution was popularly approved on November 7,1982 by 91.4 percent of the voters.

The 1982 Constitution, once again reflecting the values and interests of state elites, was even less trustful than its predecessor of the "national will"-elected assemblies, political parties, politicians, and all other civil society institutions such as trade unions, professional organizations, and voluntary associations. Trade unions were weakened and the freedom of association was severely restricted. No cooperation was allowed between political parties on the one hand, and unions, professional organizations, foundations, associations, and cooperative societies on the other. If the 1982 Constitution somewhat curbed the review powers of the judiciary and the autonomy of the universities, this was not intended as a measure to strengthen the hands of elected assemblies and responsible governments at the expense of bureaucratic agencies. Rather, the intention was to create a strong presidency, which the makers of the 1982 Constitution (themselves almost all military officers and civilian bureaucrats) assumed would be controlled by the military for a long time to come. Indeed, General Evren, the leader of the 1980 coup, served as the president of the Republic until November 1989. A major difference between the making of the 1961 and 1982 constitutions is that, in the latter case, the military no longer had much 
trust in civilian bureaucratic agencies, which it perceived as already highly fragmented and infiltrated by political parties and vulnerable to various kinds of radical political ideas. Therefore, the president of the Republic was given important substantive powers in the oppointment of high-court judges and university administrators, the two areas considered particularly sensitive by the military. In short, the 1982 Constitution was designed to maintain the military as the ultimate guardian and arbiter in the political system through a strengthened presidency and a strengthened National Security Council.

This emphasis on the strengthening of the presidency led to different interpretations of the system of government created by the 1982 Constiution. Some observers perceived it as a presidential or semi-presidential system. Another view held that the Constitution provided two alternative models of government: if the system functions normally (i.e. without a crisis) it will be closer to a parliamentary government in which the prime minister, not the president of the Republic, will predominate. This is precisely what happened under the premiership of Turgut Özal (19831989). If on the other hand, the party system fails to avoid or resolve crises, then "the substitute power" of the president (or of the state apparatus as personified by the president) will grow and the system will become closer to presidentialism (Çaðlar, 1990: 103-110). According to a third view, the logic of the 1982 Constitution dictates parliamentarism, even though the president is more powerful than most heads of state in parliamentary systems. Therefore, borrowing a French term (parlementarisme attenué) the 1982 Constitution's system of government can best be described as a modified or weakened form of parliamentarism (Özbudun, 1993: 307-312). This reading of the Constitution appears to be more consistent with the constitutional practice as it has evolved since the return to democracy in 1983. The system functioned essentially as a parliamentary government not only when Özal was both the prime minister and the leader of the majority party, but also during the premierships of Mesut Yýlmaz, Süleyman Demirel, and Tansu Çiller (Heper, 1990: 299-319).

\section{Debates on Constitutional Change Since 1983}

The 1982 Constitution, made under the aegis of the military excluding all political parties and other institutions of civil society and approved by a referendum of highly dubious legitimacy, became a matter of public debate and contestation almost from the date of its adoption. However the Motherland Party (MP), which was the majority party between November 1983 and October 1991, did not seem to be in favor of major constitutional revisions. Özal often expressed the view that the new institutions created 
by the 1982 Constitution should be given a chance to function for a while before amendments can seriously be considered. Also underlying this position was his desire to avoid an open confrontation with President Evren who had declared himself the "guarantor" of the 1982 Constitution. At a more general level, Özal often stated that the 1982 Constitution was exceedingly detailed and that its rigidity obstructed the dynamism of government. In this context, he even proposed a constitution that would only consist of a bill of rights. The MP leaders also spoke, from time to time, in favor of a constitutional amendment to transform the system of government into a semi-presidential one by having the president of the Republic directly elected by the people and by increasing his powers. However, on none of these points has a clear party policy evolved, nor have these proposals been energetically pursued.

As for the two major opposition parties (the Social Democratic Populist Party-SDPP-and the True Path Party-TPP) in the 1983-1991 period, they both produced highly detailed constitutional projects. The SDPP project envisaged a classical parliamentary system in which the president of the Republic would be elected by a three-fifths majority of the parliament (to assure his impartiality) and would have very limited powers. The SDPP project also emphasized the strengthening of the independence of the judiciary, increasing the autonomy of the universities, and lifting the restrictions on the political activities of trade unions and other civil society institutions. In a sense, the SDPP project meant a return to the basic features of the 1961 Constitution. The TPP project, on the other hand, envisaged a more radical departure from the Turkish constitutional tradition by proposing a semi-presidential system, clearly inspired by the French Fifth Republic model. According to the TPP project, the president of the Republic would be elected by the people through a two-ballot system. He would have the power to dissolve the Assembly at his own initiative, to submit laws to referendum, to return laws to the Assembly for reconsideration (in which case the latter could override the presidential veto not by simple majority but by an absolute majority of its full membership), and to determine the fundamental principles of national security and foreign policies. The President would also be the head of the Supreme Council of the Judiciary and therefore have the power to veto the nominations for judges proposed by the Council. The TPP project also envisaged the removal of certain restrictions on civil liberties and on the political activities of civil society institutions such as trade unions and voluntary associations (Cevheri, 1991).

The only significant amendment to the Constitution during the years of the MP government was adopted by the Law No. 3261, dated May 18, 1987. A part from two relatively minor and noncontroversial changes which 
lowered the voting age from 21 to 20 and increased the number of deputies from 400 to 450 , the amendment consisted of the change in the amendment procedure itself and the repeal of provisional Article 4, which had banned political activities of former political party leaders. The amendment procedure was changed in order to make constitutional change somewhat easier. The amended Article 175 provides for two different methods of amendment. One requires a less stringent majority for the adoption of constitutional changes: if the Turkish Grand National Assembly passed an amendment by a majority greater than three-fifths but less than two-thirds of its full membership, such a bill can become a constitutional amendment, provided that it is approved by a popular referendum. In such cases, constitutional referendum is mandatory, if the President does not return the bill to the Assembly for reconsideration. If he does so, then the amendment procedure becomes identical with the second method: if a proposed amendment is adopted by the Assembly by a two-thirds majority of its full membership, the President has the power to submit it to referendum. In this case referendum is optional as opposed to the first method of amendment. In short, the 1987 amendment made the Constitution somewhat more flexible than it had been, and increased popular control over constitutional change by broadening the scope of referenda. In a referendum a simple majority of the total number of valid votes cast is sufficient for amendment. Prime Minister Özal defended the change in the amendment procedure, pointing out that in the past, the failure of political parties to agree on constitutional amendment in order to obtain the required two-thirds majority of parliament led to deadlocks in the political system and, hence, constitutional changes had only been possible during periods of military takeover. Therefore, he added, constitutional change should be facilitated by giving the final word to the people in case of a parliamentary deadlock (TBMM Tutanak Dergisi, 1987: 302).

The second important constitutional amendment made by the Law No. 3261 (May 18, 1987) was the repeal of the ban on the political activities of former party leaders. Although none of the political parties represented in the Assembly made any statements favoring the continuation of the ban, the MP insisted that the repeal be submitted to a referendum. The opposition parties argued, on the other hand, that the ban should be repealed by the parliament alone and that a referendum was both unnecessary and undemocratic. The fundamental political rights of individuals, the opposition insisted, should not be put to test in a referendum. At the end, however, the TPP deputies, anxious to see an end to the ban, joined the MP majority to vote for the conditional repeal of the ban. The referendum held on September 6, 1987, approved the repeal of the ban by a hair-breadth 
majority (50.1 percent). While all opposition parties supported the repeal in the referendum campaign, the MP opposed it.

In 1988, an attempt was made to change Article 127 of the Constitution concerning local elections through the new amendment procedure. The amendment, passed by the Assembly by more than a three-fifths but less than a two-thirds majority, was automatically submitted to referendum and rejected by a popular majority of 65 percent. The results of these two referenda suggest that most voters tends to vote on the basis of their party loyalties, rather than on the merits of the proposed consti-tutional amendments.

The elections of October 20, 1991, put an end to the MP government and brought to power a coalition government of the TPP and the SDPP. As both parties have been highly critical of the 1982 Constitution in opposition and both promised sweeping constitutional changes in their election campaigns, one would have expected a much greater momentum in constitutional change, despite the fact that the combined parliamentary strength of the two parties fell short of the required two-thirds majority and even short of the three-fifths majority. The parliamentary arithmetic made it necessary to obtain the support of the MP, the major opposition party, or of all the other minor opposition parties for constitutional change.

Nevertheless, negotiations took place between the two coalition partners in order to find a common ground for proposing constitutional amendments with the expectation that other parties may also lend their support. The SDPP was, in principle, in favor of an entirely new constitution. Given the practical difficulty of accomplishing this aim, however, it presented a draft in which 75 articles of the 1982 Constitution were retained, 96 articles revised, 23 articles abolished, and one new article was drafted (TBMM'de Temsil Deðipikliði Konusundaki Görüp ve Önerileri, 1993: 122-173). The TPP did not present a full draft, but proposed changes in some 30 articles (TBMM'de Temsil Edilen Partilerce TBMM Bapkanlýdýna Sunulan Anayasa Deðibikliði Konusundaki Görüp ve Önerileri, 1993: 37-38). The TPP and the SDPP agreed on the texts of some 20 articles: Article 13 (restrictions on fundamental rights and freedoms), Article 26 (freedom of expression), Article 28 (freedom of the press), Article 30 (protection of printing facilities), Article 33 (freedom of association), Article 34 (freedom of assembly), Article 67 (right to vote), Article 68 (political parties), Article 69 (rules governing the activities of political parties), Article 76 (eligibility to become a member of parliament), Article 81 (the oath of the members of parliament), Article 92 (authorization of the use of Armed Forces), and Article 133 (radio and television broadcasts). There was also agreement on the repeal of the provisional articles, and agreement in principle on a 
number of other points (TBMM'de Temsil Edilen Siyasi Partilerin Anayasa Deðibikliði Tekliflerinin Karpýlaptýrmalý Metinleri, 1993: XI-XIV).

At this point, Hüsamettin Cindoruk, the Speaker of the Grand National Assembly invited all the parties represented in the Assembly, to present their views on the Constitution. This was followed by meetings of party leaders, presided by Cindoruk, with a view to obtaining agreement on those articles able to muster the necessary two-thirds majority. It appeared that on some articles there was indeed such a potential majority. However, the work of the inter-party committee was interrupted for a long time due to political circumstances such as the death of President Özal, the election of Demirel as the president of the republic, Tansu Çiller's becoming the prime minister and the leader of the TPP, and finally the local elections of March 1994. In the meantime, only the amendment concerning Article 133 has been separated from the others because of its special urgency and approved by a two-thirds majority of the Assembly. Thus, state monopoly over radio and television broadcasts was abolished.

The inter-party committee resumed its work in the spring of 1994, again on the initiative of the Speaker of the Assembly, Cindoruk. After painful and protracted negotiations, 14 articles were amended on July 23, 1995. The amendments repealed bans on the political activities of trade unions, associations, foundations, cooperatives, and public professional organizations, and allowed political cooperation between political parties and such civil society institutions. They lowered the voting age to 18 , increased the number of the TGNA members to 550, gave the right to vote to Turkish citizens living abroad, recognized the right to unionize (but not the right to strike or the right to conclude collective agreements) for civil servants, allowed the faculty and students in the institutions of higher education to become members in political parties, lowered the age at which one can become a party member from 21 to 18 , and permitted political parties to establish women's and youth branches, foundations, as well as organizations in foreign countries. The circumstances under which the TGNA membership is lost were also changed. Thus, changing one's political party is no longer a cause for the loss of the TGNA membership. Similarly, if a political party is outlawed by the Constitutional Court on account of its anticonstitutional activities, only those members of parliament who caused such a decision by their own words or deeds would lose their membership, but the status of other party deputies would remain unaffected. Thus, the amendments were mostly related to the political participation dimension of the Constitution, but did not bring about improvements with regard to fundamental rights and liberties. Although less comprehensive than needed and expected, the 1995 amendments nevertheless provide an example of inter-party cooperation which is not one of the distinguishing 
marks of Turkish politics. The Islamist Welfare Party did not vote for any of these amendments, insisting that the amendments include a softening of the provision on secularism (Art. 24).

\section{Constitutional Change and Democratic Consolidation}

The history of constitution making in Turkey described above suggests that none of the three republican constitutions was made by a broadly representative constituent assembly through a process of negotiations, bargaining, and compromise. In all three cases, as well as in the extensive constitutional revisions of 1971 and 1973, the influence of the state elites was predominant in constitution making, and the role of the civil society institutions was correspondingly negligible. Therefore, all three constitutions enjoyed weak political legitimacy and, judged by the frequency of military interventions in politics, none of them produced a fully consolidated democratic regime.

Clearly, the 1982 Constitution, which is a product of a highly unrepresentative process, has not found acceptance in the most important political sectors of Turkish society. All political parties, no matter what their differences are, seem to be in favor of changing the Constitution in a more liberal, pluralistic, and participatory direction. This is also the position taken by other major civil society institutions that have expressed their views on the Constitution, such as the TÜSÝAD (Turkish Industrialists and Businesspersons' Association), the Turkish Confederation of Employers' Unions, the Press Council, and the two major trade unions, Türk-Ýp and Hak-Ýp (TBMM Bapkanlýdýna Bazý Kurum ve Kuruluplarca Verilmip ve Ayryca TBMM'deki Siyasi Partilerin ve Anayasa Dedibiklidine Ýlipkin Hazýrlýk Çalýpmalarý ve Taslak Metinler, 1993: 5-230). With regard to the degree of acceptance of present political institutions by the general mass public, scant public opinion data exist. However, one recent study carried out in 1990-1991 has shown that 50.3 percent of respondents had no or little trust in the Turkish political system, and 41.9 percent had no or little trust in the Grand National Assembly. Compared to the much higher levels of trust for other social institutions (91.4 percent had high or moderate trust in the Armed Forces, 67.1 percent in religious institutions, 66.8 percent in the education system, 63.4 percent in the police) these findings are interesting and may well give rise to concern (Türk Toplumunun Deðerleri, 1991: 22-23).

Explaining this paradox is not easy. Perhaps one reason is the weakness of linkages between political parties and other civil society institutions. Such linkages, never strong, were further and deliberately weakened by the 1982 Constitution. The result is increased volatility of party votes (that 
is percentage changes in party votes from one election to the next) and the relative insulation of political parties from societal demands and pressures. Recent inter-party maneuvering on constitutional change suggest that parties tend to see such change as an essentially political game in which they are reluctant to collaborate with their adversaries unless their own favorite items are included in the "package."

Another reason may be that the emergence of two highly divisive issues in Turkish politics has made it even more difficult for political parties to agree on the broad outlines of a new constitutional order. One of these issues is the rise of political Islam as represented by the Welfare Party. The other is the ethnic issue which involves not only the violent separatist activities of the PKK (Kurdistan Workers' Party) but also the demands of some other Kurdish groups for a separate cultural or political identity. Admittedly, both issues present very important constitutional problems difficult to resolve such as Islam versus secularism, unitary state versus federal or regional state, centralization versus decentralization, Turkish nationalism versus minority rights. One is tempted to conclude that a full consolidation of Turkish democracy will not be accomplished unless political parties find enough common ground on these major constitutional issues.

\section{References}

Bonime-Blanc, Andrea. 1987. Spain's Transition to Democracy: The Politics of Constitution-Making. Boulder: Westview Press.

Çaðlar, Bakýr. 1990. "Anayasa Mahkemesi Kararlarýnda Demokrasi," (Democracy in the Constitutional Court Decisions) in Anayasa Yargýsý, 7: 53-127.

Cevheri, Necmettin. 1991. Ýpleyen Rejim, Ýpleyen Devlet (Functioning Regime, Functioning State). Ankara: True Path Party, 1991.

Heper, Metin. 1990. "The Executive in the Third Turkish Republic," Governance, 3: pp. 299-319.

Maravall, Jose Maria and Julian Santamaria. 1986. "Political Change in Spain and the Prospects for Democracy," in Transitions from Authoritarian Rule: Southern Europe, Guillermo O'Donnell, Philippe C. Schmitter, and Laurance Whitehead, eds. Baltimore: Johns Hopkins University Press.

Özbudun, Ergun. 1993. Tïrk Anayasa Hukuku (Turkish Constitutional Law). Ankara: Yetkin Yayýnlarý.

Pasquino, Gianfranco. 1986. "The Demise of the First Fascist Regime and Italy's Transition to Democracy, 1943-1948," in Transitions from Authoritarian Rule: Southern Europe, Guillermo O'Donnell, Philippe C. Schmitter, and Laurence Whitehead, eds. Baltimore: Johns Hopkins University Press.

Tanör, Bülent. 1986. Ýki Anayasa: 1961-1982 (The Two Constitutions: 1961 and 1982). Istanbul: Beta. 
TBMM Bapkanlýð̆ýna Bazý Kurum ve Kuruluplarca Verilmip ve Ayrýca TBMM'deki Siyasi Partilerin Anayasa Deđipikliðine Ýlipkin Hazýrlýk Çalýpmalarý ve Taslak Metinler (Preperatory Studies and Draft Texts Concerning Constitutional Amendments, as Presented to the Speaker of the TGNA by Certain Institutions and Associations and by Political Parties Represented in the TGNA). 1993. Ankara: TBMM Bapkanlýóý, February 22.

TBMM'de Temsil Edilen Siyasi Partilerce TBMM Bapkanlýð̆́na Sunulan Anayasa Deðipikliði Konusundaki Göriip ve Önerileri (The Views and Proposals of Political Parties Represented in the TGNA Concerning Constitutional Amendments, as Presented to the Speaker of the TGNA). 1993. Ankara: TBMM Bapkanlýðý, March.

TBMM'de Temsil Edilen Siyasi Partilerin Anayasa Deð̋ikikliði Tekliflerinin Karpýlaptýrmaly Metinleri (Comparative Texts of the Proposals of Political Constitutional Amendments). 1993. Ankara: TBMM Bapkanlýðý, March.

TBMM Tutanak Dergisi (Verbatim Report of the TGNA Debates). 1987. Dönem 17, Yasama Yýlý 4, Cilt 40, Birlepim 102. May 13.

Türk Toplumunun Deðerleri. 1991. (The Values of the Turkish Society) Istanbul: TÜSÝAD. 